\title{
The Prison Conditions Cases and the Bureaucratization of American Corrections: Influences, Impacts and Implications
}

\author{
Malcolm M. Feeley* \\ Van Swearingen**
}

\section{Introduction}

By almost any measure, it is clear that, over the past thirty years, litigation has had a dramatic impact on the nation's jails and prisons. New doctrine has become part of the established legal landscape. ${ }^{1}$ The Plantation Model, securely ensconced in southern prisons as late as the 1970 s, is now socially unacceptable and has been largely dismantled. ${ }^{2}$ Sadistic treatment at the hands of inmate trustees is a thing of the past. Instruments of torture routinely employed in Southern prisons just a few years ago have been relegated to the museums. Inmates can now expect to receive nourishing meals and adequate medical care. Nowadays, basic services and amenities are routinely made available to all prisoners. And although these practices and expectations are at times honored in the breach, officials feel compelled to lie about or acknowledge problems and promise remedies when failures are exposed. It has now become socially unacceptable to acknowledge many practices that just a few short years ago were standard operating procedures or reconciled as regrettable by-products of a challenging task.

* Malcolm M. Feeley is a Claire Sanders Clements Dean's Professor of Law at the University of California, Berkley. He has written numerous articles and is the author of several books including Judicial Policy Making and the Modern State. $\mathrm{He}$ is a graduate of Austin College and holds an M.A. and Ph.D. from the University of Minnesota.

** Van Swearingen is a graduate of the University of Texas at Austin and holds an M.P.P. from the Goldman School of Public Policy at the University of California, Berkeley.

1. Malcolm M. Feeley \& Edward L. Rubin, Judicial Policy Making and the Modern State: How the Courts Reformed Americas' Prisons (1998).

2. See id. at 39-41. 
Of course it is easy to overstate the benefits of litigation and court orders. Judicial decrees have not been uniformly effective; old patterns have reappeared as soon as courts have turned their attention elsewhere or terminated jurisdiction. Prison officials have responded with symbolic rather than real responses. And with mounting prison populations, even wellintentioned officials have seen their institutions regress. Furthermore, in light of the historical cycle of neglect, violence, crowding, scandal, reform, and the revulsion Americans feel towards criminal offenders, it would be foolhardy to expect that a handful of litigators and federal judges acting by themselveseven over the course of thirty odd years-could fundamentally alter the structure and culture of America's prisons and jails. Whatever they are, prisoners' rights groups are not major powers in American political life, and courts are not powerful vehicles for social change. ${ }^{3}$ Still, despite these limits, judicial intervention in prison conditions appears to be a distinct and singular success. ${ }^{4}$

The question is: why? In the face of so many failures, why have the courts been at least relatively successful in formulating and implementing orders affecting prison conditions? In an earlier examination, Feeley and Rubin explored at great length the distinctive techniques the courts have used to define and attack the problem of prison reform, and that analysis goes some considerable way to explain how courts were ultimately successful in such endeavors. ${ }^{5}$ Although we quickly review some of the features of the courts' approach below, the thrust of the discussion that follows attributes the relative success of the courts to several other factors as well. As Feeley and Rubin noted earlier, the judges in such cases abandoned their traditional judicial role as "interpreters" of preexisting norms and explicitly embraced a policy-making role. ${ }^{6}$ However, these judges did not act alone. As policy makers, they drew on and reinforced powerful national trends that were already well un-

3. See, e.g., Gerald Rosenberg, The Hollow Hope: Can Courts Bring About Social Change? (1991) (arguing that courts by themselves can never effect significant social change).

4. See generally, Feeley \& Rubin, supra note 1.

5. See id.

6. See id. at 13-15. 
derway by the time they were drawn into the reform effort. Furthermore, when these judges did become involved, far from cutting across the currents of these reform efforts, they drew on and reinforced them. Finally, these superintending judges selfconsciously sought institutionalized reforms by strengthening the organizational capacities of correctional systems through increased bureaucratization.

Part I of this article explores the distinctive policy-making approach that was pressed upon receptive judges by creative litigators. Part II examines how litigation both drew upon and fostered other powerful and parallel reform efforts. Part III describes how the courts enhanced and deepened the bureaucratic capacities of prisons and prison systems. A concluding Part IV reflects on the implications of increased bureaucratization, finding in it mixed, though overall positive, consequences. $\mathrm{Al}$ though bureaucracy is an effective way to improve safety, security, and services for prison inmates, and for tightening supervision and accountability of correctional officers, it also enhances the capacity to control. Thus the most distinctive accomplishment of prison conditions litigation is something of a double-edged sword. Even as it has enhanced prisoners' rights, it has strengthened officials' capacity to control.

Similar observations have been made earlier. Nearly twenty-five years ago, even before prison conditions litigation hit full stride, James Jacobs identified the trajectory that prison conditions litigation had taken, and outlined a "strategy for evaluating the impacts of the prisoners' rights movement." $\mathrm{He}$ argued that the prisoners' rights litigation must be understood as part of a more general movement of "victimized minorities," and saw it as "part of a [broader] mosaic of social change" that would not have been possible without activism of the federal judiciary and some stamp of approval by the justices of the United States Supreme Court." He then went on to note that "a complete sociopolitical history of the prisoners' rights movement would have to take federal and state legislative and administrative activity into account,"9 and concludes that its most endur-

7. James B. Jacobs, The Prisoners' Rights Movement and Its Impacts, 1960 1980, in 2 CRime AND Justice 430 (Michael Tonry et al. eds., 1980).

8. Id. at 432 .

9. Id. at 434 . 
ing effect was to increase both the professionalization of correctional personnel and the bureaucratization of correctional organizations. ${ }^{10}$ Although this article does not attempt the comprehensive analysis that Jacobs proposed, it does address two of his central concerns, the involvement of other branches of government and the increased rationalization of correctional institutions.

\section{Judges as Policy Makers}

Judicial intervention is admittedly an odd way to reform prisons, but the litigators who brought the cases and the judges who ruled on them were not unaware of, nor unsympathetic to, this observation. ${ }^{11}$ Consequently, despite the language of individual rights that gives rise to and shapes so much constitutional litigation, prison conditions cases were about institution building: clarification of basic mission, insistence on tight and responsible administration, development of written policies, cajoling legislatures to increase funding, and garnering public support for change. These goals were not explicitly articulated by prisoners' counsel or judges in these cases, but they were loosely and intuitively embraced by both. The unarticulated reason: in the "organization society," the protection of individual rights requires competent and constrained administration. Bureaucracy fosters rules, supervision, and accountability, and in so doing substitutes the rule of law for the will of the ruler.

This concern with structure and organization emerged almost at the outset, in response to challenges in the earliest and most egregious cases that came from the South, where a dis-

10. For a similar discussion on developments in police administration particularly in "pattern and practice," cases see Samuel Walker, The New Paradigm of Police Accountability: The U.S. Justice Department "Pattern and Practice" Suits in Context”, 22 St. L. U. Pub. L. Rev. 3 (2003). See also, Samuel Walker, Taming the System: The Control of Discretion in Criminal Justice, 1950-1990 (1993) [hereinafter Taming the System].

11. The traditional model of the judicial role limits judges to fact finding and interpreting pre-existing rules. However, at times judges can and do make policy. By policy we mean identifying a goal-an end-and then self-consciously taking steps to reach that goal. For an extended examination of policy making as a normal role of judges see FEELEY \& RUBIN, supra note 1 at 204-96; Edward L. Rubin \& Malcolm M. Feeley, Creating Legal Doctrine, 69 S. CAL. L. REv. 1989 (1992); see generally, Edward L. Rubin \& Malcolm M. Feeley, Judicial Policy Making and Litigation Against the Government, 7 U. OF PA. J. OF Const. L 617-64 (2003). 
tinct model of the prison had long been entrenched. Here prisoners not only routinely faced unspeakable cruelty and inadequate resources, but were subjected to a wholly distinct prison culture that did not exist elsewhere in the United States. The Southern model, derived from the slave plantation, envisioned a self-contained, self-sufficient prison, subsisting on goods and services provided by prison labor, and which, like the plantation of old, could be run at a profit. ${ }^{12}$ Throughout its history, the plantation prison system did occasionally operate as planned and return funds to the state. But even when it did not, relative to prisons in other parts of the nation, it was inexpensive. The plantation model depended upon inmate rather than free-world guards, quartered prisoners in squalid barracks not cells, engaged them in forced labor, and denied them basic services and amenities. ${ }^{13}$ In many respects the results were worse than slave plantations. Slave owners had incentives to protect their human capital. Prison officials had none; slaves of the state were disposable. This was the reality confronting federal judges as they faced constitutional challenges to prison systems in the South. Reform required not just improvement but a reconceptualization of the enterprise. The situation in the North and West was different. There the plantation model had never taken hold and modern practices of penology and public administration had been embraced in name, if not in fact. ${ }^{14}$ In these areas, the problem was not a failure of vision, but a failure of practice. Still, here too, the challenge was immense, and once the courts had come to a conception of the modern, constitutional prison, this model was used to assess prisons outside the South as well. ${ }^{15}$

Once they adopted this challenge, judges were forced to become policy makers and administrators. And like all good administrators, they depended on experts for guidance. Initially when formulating remedial orders, they relied on the testimony of well-regarded correctional administrators who had served as expert witnesses. ${ }^{16}$ Later, when they were on the verge of be-

12. FeEley \& Rubin, supra note 1 , at 153.

13. Id.

14. Id. at $150-51$.

15. Id. at $169-70$.

16. Feeley \& Rubin, supra note 1 , at 307. 
coming bogged down with the task of implementing their orders, they turned to a similar group of qualified authorities to serve as special masters and monitors. ${ }^{17}$ Nowhere did judgesor prisoners' rights lawyers-attempt to innovate on their own. Nowhere did judges offer a new or novel approach to penology. Nowhere did any judge strike out boldly to promote new alternatives. Nowhere did they even draw on penological thinking from outside the United States. Although many lawyers who brought the cases, and perhaps even some judges who decided them, may have occasionally dreamed about more far-reaching reforms, none apparently asked a court to consider them seriously. Rather, the litigators and the judges in these cases sought out and relied on the best and the brightest among the acknowledged leaders in American corrections. The master conclusion that linked this disparate group of successful litigators and judges and permitted them, almost overnight, to become involved in the minute details of prison administration was bureaucratization and rehabilitation. These were not new and novel ideas, but the best of conventional thinking that had long been advocated by reform-minded prison officials themselves.

Indeed, one need look no further than the 1959 edition of the Manual of Correctional Standards, ${ }^{18}$ published by the American Correctional Association (ACA), the professional association of prison officials, to find the perspective embraced by the courts in the prison and jail conditions cases in the 1970s. Initially published in 1946 and revised periodically thereafter, this volume set forth a host of standards that are grounded in the ideas of bureaucratization and rehabilitation. ${ }^{19}$ Since its first publication, the Manual has been the Bible that has shaped the thinking of correctional administrations and guided prison reform efforts. Once these professionals embraced a policy-making stance, it is no small wonder that the courts seized upon it as well.

In the worst prison systems, those in the South, the judges confronted cruelty, torture, and outmoded, feudal-like institutions; here the task of the courts was to transform them into

17. Id. at 309.

18. Am. Corr. Ass'n, Manual of Correctional Standards (1959).

19. See id. 
modern bureaucratic institutions. Somewhat later in the North, the courts confronted dispirited prison systems that could not manage according to their own rules. And everywhere, they discovered under-performing institutions whose leaders grudgingly acknowledged that they were unable to implement what they knew to be their responsibilities. In all of these cases, judges embraced conventional penological thinking, not some new and untested idea. In Arkansas, for instance, Judge Henley drew heavily on the testimony of James V. Bennett, ${ }^{20}$ former head of the Federal Bureau of Prisons (BOP), who, in essence, recommended that the state adopt standard BOP policies. Judge Henley, and the other judges who came after him, followed this advice. Far from undermining correctional management, they sought to strengthen it. Realizing this, these experts quickly came to see that litigation provided them with a bully pulpit.

This alone, however, would not have ensured success. For instance, courts were not able to act so decisively and effectively in cases involving challenges to conditions in mental institutions. Like prisons, state mental institutions have a long history of neglect and abuse, and indeed the first big "institutional conditions" case was brought against Alabama's state mental institutions. ${ }^{21}$ Here too, after some hesitation, the courts embraced the challenge. And here as well, judges turned to experts. However, they found that experts disagreed vigorously on what to do with the seriously mentally ill. Some favored deinstitutionalization. ${ }^{22}$ Others embraced the idea of community-assisted living in group homes. ${ }^{23}$ Still others favored reforming the large-scale institutions, where professional staffs and programming were available around the clock. ${ }^{24}$ This lack of consensus frustrated litigators and judges; when they looked

20. See, e.g., Holt v. Sarver, 309 F. Supp. 362 (E.D. Ark. 1970); Jackson v. Bishop, 268 F. Supp. 804 (E.D. Ark. 1967), vacated by, 404 F.2d 571 (8th Cir. 1968).

21. See Wyatt v. Stickney, 325 F. Supp. 781 (M.D. Ala. 1971).

22. See generally Alina Perez et al., Reversing the Criminalization of Mental Illness, 49 CRIMe \& Delinquency 62 (2003).

23. See Council of State Gov't, Criminal Justice/Mental Health Consensus PROJECT 136-51 (2003), available at http://consensusproject.org/downloads/Entire_report.pdf

24. See Citizen's Comm. on Mental Illness, Substance Abuse, and Criminal Justice \& Nami Maine, Report on the Current Status of Services for 
at the existing institutions they were revolted by what they found, but they could not turn to a ready-made model as a replacement. As a consequence, institutional litigation against mental institutions cannot be judged a success. In contrast, there was consensus among experts as to what a good prison should look like. Judges seized upon this model, adopted it as their own, and set about implementing it.

Judges embraced policy making in prison conditions cases in still another way. They acquired staffs. As students of public policy have come to realize, much policy is made in the process of implementation, through the continual adjustment between policy makers and operational administrators as general goals are translated into a myriad of detailed plans that must confront the reality of the work place. ${ }^{25}$ Judicial policy making in the prison conditions cases followed this process. Initial court orders read like reports of legislative committees or administrative agencies. They contain long recitations of findings that identify a problem and then point towards a solution. But they leave the details to be worked out later by the affected institutions. However, when it became clear that corrections officials were unwilling or unable to attend to these details and develop meaningful plans for implementation, the judges were drawn more deeply into the implementation process, and demanded still more detailed plans. Eventually they turned to experts for help. They appointed special masters to assist them-and the parties-in finding facts, developing implementation plans, and monitoring compliance. This expanded capacity of the courts further merged the process of policy making and implementation in just the ways that students of public administration describe. If in these cases judges appropriated the role of agency heads, special masters in effect became their special assistants. Masters served all the roles commonly attributed to executive assistants. Like special assistants everywhere, they were intensely loyal to their bosses and to their mission. And like special assistants everywhere, ill-defined roles allowed them to

Person with Mental Illness in Maine's Jails and Prisons: 2002 (2002), available at http://www.prisonsucks.com/scans/maine/maine_mental_illness_2002.pdf.

25. Jeffrey Pressman \& Aaron Wildavsky, Implementation: How Great Expectations in Washington are Dashed in OAKLAND (3d ed. 1984). 
exercise the authority of their bosses. ${ }^{26}$ Given near free-range to roam through the prisons, special masters served as eyes and ears for their bosses, and thus allowed their judges to stay on top of problems without becoming bogged down in details. And because they often had backgrounds in prison administration, they were a valuable source of expertise for their judges, all the more so because their communications were unmediated by cumbersome adversarial proceedings.

Although the legal process school holds that the form of adjudication also prescribes its limits, ${ }^{27}$ prison conditions cases refute this assertion. As they shifted functions and embraced policy making, the courts took on new forms. They were goaldirected problem-solvers. They embraced executive-like policymaking; they engaged in the nitty-gritty of implementation where policy battles are often won or lost; and when they were on the verge of getting bogged down, they acquired staffs. ${ }^{28} \mathrm{Al}$ though reasonable people might assess the results of these efforts differently, as would be the case with policy making generally, what is less disputable is that by embracing this stance, judges dramatically expanded their capacities. By acquiring the accoutrements of policy makers, judges succeeded as policy makers. And for the most part they adopted the sorts of policies that prison officials themselves would have wanted. This is hardly surprising, since the courts-like reformedminded administrators-took their ideas from experts in the field.

26. This has occasioned a great deal of complaints. Critics argue that the role of special masters should be established and bounded at the outset. See generally James S. DeGraw, Rule 53, Inherent Powers, and Institutional Reform: The Lack of Limits on Special Masters, 666 N.Y.U. L. REv. 800 (2001); Susan P. Strum, A Normative Theory of Public Remedies, 79 Geo. L. Rev., 1355 (1991). Yet, every study of the tasks of special masters emphasizes just how contingent and unpredictable the job is. See David L. Kirp \& Gary Babcock, Judge and Company: Court Appointed Masters, School Desegregation, and Institutional Reform, 32 ALA. L. REv. 313 (1981); see also Sturm, supra.

27. See Lon Fuller, The Forms and Limits of Adjudication, 92 HARv. L. REv. 353 (1978); RuBIN \& FEELEY, supra note 1, at 330-33.

28. At the height of the Texas prison conditions case, Ruiz v. Estelle, $161 \mathrm{~F} .3 \mathrm{~d}$ 814 (1998), Judge Justice's special master was the size of a small law firm or research unit, with a staff of fourteen and a budget of over one million dollars per year. See FeEley \& Rubin, supra note 1, at 86-90. 


\section{Prison Conditions Litigation and the National Political Process}

To conclude that the courts adopted a policy-making stance and set about implementing a ready-made model provided by the corrections profession does not mean that their task was or could have been accomplished through litigation alone. The cumulative effect of the judicial intervention was substantial, in both its direct and indirect effects. Indeed, litigation has probably been the single most important source of change in prisons and jails during the past forty years. Yet the greatest effect of this litigation was to consolidate efforts that were being promoted and pursued in several settings simultaneously. Bold litigation strategies and dramatic court orders provided a substantial additional impetus to these efforts, but litigation did not occur in isolation. As has already been suggested, litigation was successful in large because judges drew on a well-defined model that had long been promoted within the corrections field itself. ${ }^{29}$ Although many corrections officials publicly expressed indignation at being pushed into action by the courts, many secretly and not-so-secretly welcomed the lawsuits, and, as we have seen, prominent leaders came to regard the courtroom as a bully pulpit. Litigation became one more forum for promoting reform. In this sense, prison conditions litigation must be understood as both a cause and an effect of change: cause, because judges forced change upon reluctant and recalcitrant prison officials, and effect because litigation reinforced trends that were already well-underway and widely embraced.

Specifically, litigation reinforced and reflected four powerful trends; it: 1) strengthened the process of professionalization within corrections; 2) embraced and fostered national standards for corrections; 3) expanded the federal government's interest in and oversight of state and local institutions; and 4) represented the last step in constitutionalizing the criminal process. Taken as a whole, these various efforts had a tremendous impact upon inmates' conditions of confinement. They placed prison reform on the public agenda. They strengthened institutional capacity. They contributed to the recruitment of better informed and more highly trained staff, imposed increasingly stringent stan-

29. See supra notes $16-20$ and accompanying text. 
dards on correctional agencies, and they placed the weight of powerful national organizations on the side of institutional reform. Seen in this light, litigation is part of a larger mosaic of normal politics, where a variety of forces come together to change public perceptions and fashion new policies. Courts thus were neither the bold adventurers they are sometimes made out to be, nor reactive bit players limited by form and function. Rather, they were active participants in a reform process that was proceeding apace on several stages simultaneously. In the discussion below, we situate the prison conditions cases in this larger reform movement, showing how litigation was both a cause and an effect of reform.

\section{A. Reform Through Professionalization}

Prison conditions litigation enhanced and accelerated the professionalization of corrections in two important ways. It provided a new and important forum for national correctional leaders to promote ideas they had long advocated; and it fostered the recruitment of a new type of correctional administrator. In case after case, the same small handfuls of nationally respected leaders were called upon to serve as witnesses, advise the court, and serve as special masters and compliance officers. They used their newfound platforms to advocate their long-standing ideas for reform, speaking not just to likeminded colleagues as they had in the past, but to powerful judges, and through them, to powerful state legislators, governors, and newspaper editors who, as often as not, were the real audience for their testimony.

Litigation also fostered a new generation of correctional administrators who embraced the views of these national leaders and accepted the role of the courts in stimulating changes in their institutions. As late as the 1970s, the prison systems in many states remained a world apart, one of the last bastions of public service to be exempt from standard civil service requirements, modern bureaucratic structure, and meaningful political accountability. They continued to be staffed and administered by good ol' boys who were recruited through a system of patronage, and all but ignored by governors and legislators. ${ }^{30} \mathrm{Al}-$

30. See FeEley \& RuBin, supra note 1, at 182, 193; see also Christopher E. Smith, The Governance of Corrections: Implications of the Changing Interface of 
though this form of organization was being eroded by forces wholly independent of the prisoners' rights movement, litigation hastened its demise. Litigation requires articulate, knowledgeable officials who are able to defend institutional practices and prepare and respond to written regulations, not bumbling yokels who defend practices according to their own predilections and whose policies change with each shift. With its emphasis on due process, administrative regularity, written rules, and the like, litigation fostered the recruitment and promotion of officials who were comfortable doing these things. In courtroom after courtroom, old-style administrators simply could not cope. They could not describe operations clearly, they could not defend practices in terms of written rules and standards and they could not formulate satisfactory plans for change. Eventually they were replaced by better educated, more professionally oriented officials who could and would do these things. ${ }^{31}$ This does not mean that judges themselves fired old officials and hired new, professionally oriented replacements-although at times they did just this. Rather, when state and local officials saw that incumbents could not deal effectively with the courts, they appointed those who could. And these officials were likely to be reform-minded correction officials more in tune with modern correctional views and national standards. For instance, in Santa Clara County, California, the board of supervisors first accepted the de facto receivership that placed the jail in the hands of an experienced correctional administrator appointed by the court, and then in effect fired the elected sheriff and replaced him with an experienced correctional administrator. ${ }^{32}$ In Texas, the top rung of the old-style leadership was eventually replaced by professionals with experience in military prisons, and still later with a director whose background was in account-

Courts and Corrections, in 2 CRIMINAL JUSTICE 2002, at 117 (2002), available at http://www.ncjrs.org/criminal_justice2000/vol_2/02e2.pdf.

31. Nathan Glazer argues that it promotes those with "theoretical knowledge" and more education over those with "practical knowledge" gained from experience. At least in respect to school administration, he argues that this yields a net loss and undermines important sources of authority. See Nathan Glazer, The Judiciary and Social Policy, in The Judiciary in a Democratic Society (L. J. Thebrese ed., 1979). We see no evidence that this is the case-in the long run-in prisons and jails that have been under extended impact of court orders.

32. See Feeley \& Rubin, supra note 1, at 120-25. 
ing and budgeting, skills that were deemed invaluable in an organization with an annual budget of over one billion dollars. ${ }^{33}$ In California until the late 1970 s, superintendents of correctional institutions almost always came up through the ranks of the security division, but by the late 1980 s eleven of the state's fourteen prison superintendents had been recruited from the ranks of prison social workers, parole agents, and education specialists-not guards. ${ }^{34}$ And everywhere litigation forced states to develop written rules and regulations for prison governance.

In some instances litigation has had an even more direct and immediate effect upon the recruitment of a new type of correctional administrator. In response to litigation, many corrections departments have established "compliance coordinators" or "litigation coordinators," whose jobs are to serve as liaisons between attorneys for the department (usually in the state attorney general's office) and the corrections department, to help coordinate the defense and, after a ruling, to help oversee compliance to the court order. Such liaison positions have become so common that the American Correctional Association and the American Jail Association have established membership sections for "compliance coordinators." From conversations with sheriffs and those active in the associations, it appears that many of the best and the brightest younger administrators are often tapped for these positions.

In these and a host of other ways, litigation promoted professionalization and facilitated opportunities for a new generation of administrators. Indeed, many of these administrators have come to regard judicial intervention in a positive light, or at least take it in stride as part of the landscape of modem correctional administration, if not public administration more generally. This of course does not mean that they all welcome judicial intervention or agree with everything a court may order. Most corrections officials find much to criticize in court orders, but this new cohort of professionals does not instinctively defy, and does not resist root and branch. They are comfortable with the idea of prisoners' rights and judicial intervention, and

33. See id. at $80-85$.

34. See id. at 120-25. 
though they may chafe at increased paper work or occasional inexplicable orders, they have no quarrel with the modem administrative structure that the courts have forced upon them. ${ }^{35}$

\section{B. Reform Through Promulgation of Standards}

Until well into the 1970 s, many local jails and state correctional systems operated without one of the central features of modern governmental agencies, a rational-legal bureaucratic structure. Such institutions were pre-bureaucratic in the most primitive sense of the term; they operated outside the mainstream of administrative developments that have, since the New Deal, become commonplace in public agencies. However, the transformation of penal institutions into modern bureaucracies began long before the onset of the prisoners' rights movement and litigation. In most jurisdictions outside of the South, litigation was probably not the primary cause of these developments. Rather, it shored up, expanded and cemented changes that were already well under way. Litigation filled in the blanks as it were, and forced more concrete and more detailed specifications. In the South, however, litigation was a major transformative force. It required corrections officials, governors and legislators to rethink and reconceive the very nature and function of their state's prison system. And even here the picture was mixed. In Texas, the court had to struggle to command the attention of corrections officials and was challenged at each step of the way. ${ }^{36}$ However, in Arkansas, Commissioner Sarver welcomed the litigation and used it to educate his subordinates and legislators. Judge Henley forced very little on Commissioner Sarver that he did not want. ${ }^{37}$

35. This observation is revealed in the numerous conversations I have had with corrections administrators.

36. See Feeley \& Rubin, supra note 1, at 80-85.

37. See generally id. at 61. Compared to other Southern states, Florida is something of an anomaly. Modernization of its prisons began well before the prisoners' rights movement and proceeded apace without any comprehensive, systemwide litigation. In the early 1960s, Florida's commissioner of corrections, Louis Wainwright, began transforming that state's correctional system along lines advocated by national corrections leaders, and by the mid-1980s Florida was the only state that had all of its prisons certified as meeting all the standards set by the American Correctional Association. Although there were a number of important cases involving Florida prisons, none required the sort of root and branch involve- 
Once they began to manage prisons, judges seized upon the ready-made standards that were urged on them by prisoners' rights lawyers and their expert witnesses. These standards were developed by professional associations and were incorporated into the regulations in the most highly regarded prison systems. In turn, seeing the use to which the courts put standards accelerated their standards-setting activities. Throughout the 1970s and 1980s a host of associations, often supported with federal funds, produced an ever-increasing variety of standards. Some associations, such as the Society of Refrigeration and Heating Engineers and the American Medical Association, were organizations of technical specialists whose primary interests were not prisons, but which nevertheless developed standards for use in institutional settings, including prisons. Others were professional groups with long-standing interests in legal affairs, such as the American Bar Association, which years earlier had developed guidelines for the administration of criminal justice as a way of staving off litigation. The national government also became involved in the standards setting process. $^{38}$ In the 1960s the Law Enforcement Assistance Administration (LEAA) provided financial support and its prestige to promote the Standards and Goals Project in conjunction with the American Correctional Association, as well as the ABA's Minimum Standards of Justice project. Similarly, the National Institute of Corrections, the U.S. Department of Justice, and the U.S. Public Health Service all promoted the advancement and adoption of national standards, practices and policies. Furthermore, federal agencies offered financial support to state and local agencies that would adopt either its standards or exemplary programs that it had funded. ${ }^{39}$

National concern for countrywide standards long predated the prison conditions litigation and in fact stemmed from the same general concern that gave rise to litigation itself, the desire to modernize the criminal process and to respond to the

ment by the courts that took place in Arkansas, Texas and elsewhere in the South. See id. at 165-66.

38. See id. at 162 . However, rather than withdrawing from the review of state criminal procedure, the federal courts used these standards when it formulated constitutional rules governing the criminal process.

39. See generally id. at 385-86. 
emergence of the rights consciousness of the 1960s. Indeed, the particular forms of rationalization that the courts imposed on the prisons probably derive more from the agenda of the American Correctional Association and the recommendations of the Task Force Reports of the President's Crime Commission of the 1960s than from any original insights provided by prisoners' rights lawyers or the courts themselves. Had these standards not been readily available, it is not clear that the courts would have created them from whole cloth.

There is always a danger that standards adopted by private associations (such as the ACA or any of the other professional organizations that promulgated standards for health care, diet, heating and ventilation, and the like in prisons) will represent the interests of the institutions they are designed to regulate rather than the interests of the public or consumers served by these interests. ${ }^{40}$ No doubt there is some truth to this fear, but as Ross Cheit has shown, standards produced by such associations are often dictated by technical judgments of professionals rather than politically concerned bureaucrats or self-serving agents of industry. ${ }^{41}$

Whatever the case, courts turned to these professional organizations and their standards with some frequency when assessing the efforts of prison officials to improve conditions in their institutions. Such efforts have had far-reaching consequences. Standards pertaining to food service, medical care, education, access to legal materials, and rehabilitation often specify not only the nature of the substantive service to be provided-say, the types of food and number of calories-but also the qualifications and training of the staff required to provide them. Thus, for instance, the Public Health Service not only sets standards for balanced diets, but also recommends that certified dieticians supervise prison kitchens and prepare this food. ${ }^{42}$ Thus, embracing one standard to deal with one especially egregious problem-for instance, to assure sanitary con-

40. See, e.g., Theodore Lowi, The End of Liberalism (1976).

41. Ross Cheit, Setting Safety Standards: Regulation in the Public and Private Sectors (1990).

42. See Federal Bureau of Prisons, Health Services Division, Food Services Branch, at http://www.bop.gov/hsdpg/hsd.html (last visited Aug. 22, 2004); see generally Smith, supra note 30, at 142-43. 
ditions in a prison kitchen-would often draw courts into a complex web of regulations. Standards come in packages.

On May 5, 1969, in Holt $v$. Sarver, ${ }^{43}$ when Judge Henley took his first tentative step towards restructuring the Arkansas prison system, he relied heavily on the testimony given by James Bennett and other experts for establishing the criteria for assessing prison conditions. ${ }^{44}$ Bennett, in turn, appears to have drawn much of his testimony directly from the Manual of Correctional Standards published ten years earlier by the American Correctional Association. Fourteen years later, Judge Henley's successor, Judge Eisele, continued to rely heavily on standards, which by then had grown considerably in volume and covered many more aspects of prison administration. Indeed, many of these standards had, since Judge Henley's first ruling, been incorporated into the state's administrative code and prison regulations. During the intervening fourteen years, standards had been both the cause and effect of the litigation. They had supplied plaintiffs' attorneys, the court, and the compliance officer with criteria for assessing a host of different conditions in the prisons, and had provided these same people with criteria for breathing specificity into general orders and assessing efforts to comply with them. In turn, the standards offered guidance to department officials anxious to take whatever steps were necessary to free themselves from the court.

We do not mean to suggest by this that litigation was responsible for the promulgation of national standards, or that federal judges seized indiscriminately upon professional standards to define constitutional minima. Professional interest in developing standards predated litigation by many years, and the courts employed a variety of other sources by which to assess conditions as well. ${ }^{45}$ But professional standards were readily available, associations were anxious to develop them and federal agencies were willing to fund and promote them. Litiga-

43. 309 F. Supp. 362 (E.D. Ark. 1970), aff'd by, 442 F.2d 304 (8th Cir. 1971). 44. See id.

45. See generally Edward L. Rubin \& Malcolm M. Feeley, 21st Annual Edward V. Sparer Symposium Suing the Government: Velaquez and Beyond: Judicial Policy Making and Litigation Against the Government, 5 U. PA. J. Const. L. 617, 657-59 (2003). 
tion provided one more impetus for both the production and the promotion of standards.

\section{Reform though the National Political Process}

Historically, Congress has regarded criminal justice administration as a state and local matter and taken great pains not to appear to encroach upon the prerogative of the states. The first big debate over this occurred with the establishment of the Federal Bureau of Investigation (FBI) in the 1920s. ${ }^{46}$ This debate is rekindled periodically each time Congress enacts federal criminal laws but is muted by the fact that, as a practical matter, federal law enforcement officials generally defer to state officials.

However, since the 1960s there has been a slow but steady increase in federal involvement in selected aspects of state and local criminal justice administration. A watershed event was the establishment of the President's Crime Commission, and the publication of its reports in the mid-1960s. ${ }^{47}$ Perhaps the major contribution of the commission was its successful introduction of the concept of a criminal justice system, a term that until publication of the commission's reports had rarely, if ever, been used. ${ }^{48}$ This admonition to develop a "system" to overcome undefined discretion and balkanization in the criminal process set the agenda for the Law Enforcement Assistance Administration (LEAA), which was established in 1968.49 LEAA's mission was to distribute federal funds to state and local criminal justice agencies in order to promote innovation and efficiency in

46. See generally Frank J. Donner, The Age of Surveillance: The Aims and Methods of America's Political Intelligence System 31-50 (1980) (discussing the creation of the Federal Bureau of Investigations).

47. See, e.g., The President's Commission on Law Enforcement and the Administration of Justice, The Challenge of Crime in a Free Society (1967); The President's Commission on LaW Enforcement and the Administration of Jus. tice, Task Force Report: The Police (1967); The President's Commission on Law Enforcement and the Administration of Justice, Task Force Report: The Courts (1967).

48. See, e.g., Malcolm Feeley \& Jonathan Simon, Actuarial Justice, in THE Futures of Criminology (David Nelken ed., 1994); see also SAmuel Walker, TaMing the System: The Control of Discretion in Criminal Justice, 1950-1990 (1993).

49. The Omnibus Crime Control and Safe Streets Act of 1968, 42 U.S.C. $\S 3701$ (repealed 1984). 
the criminal process, and in so doing to foster a national, professional perspective to replace the insularity and particularism of local criminal justice agencies. ${ }^{50}$

This trend has continued through both Democratic and Republican Administrations. In 1974, Congress established the National Institute of Corrections to provide technical assistance and advice to state and local corrections departments. ${ }^{51}$ In 1980 it passed the Civil Rights of Institutionalized Persons Act (CRIPA) to provide a statutory basis for federal involvement in litigation challenging conditions in correctional institutions, and to establish federal standards for state and local correctional institutions. ${ }^{52}$ And the Violent Crime Control and Law Enforcement Act of $1994^{53}$ continued this trend, further linking local crime policy to national concerns. As federal funds are passed on to support activities of state and local criminal justice agencies, Congress has begun to attach conditions. National crime policy follows the course of normal politics.

CRIPA in particular reveals the extent to which prison conditions reform represents a broad-based national commitment, and is far more than judicially imposed policy. Enacted by an overwhelming vote in both houses of Congress, this statute constituted an explicit recognition of the federal oversight role in state and local corrections and other institutions of confinement. The act authorizes the use of Department of Justice resources to challenge conditions that exist "pursuant to a pattern or practice of resistance" by state officials to correct conditions that are so "egregious or flagrant" as to "deprive [inmates] of any rights, privileges, or immunities secured or protected by the Constitution or laws of the United States ...."54 By providing for the creation of federally approved standards, Congress staked out an important federal interest in state and local institutions. And by authorizing federal support for legal challenges

50. See Pub. L. No. 90-351, §100, 82 Stat. 197 (1968) (setting forth the Congressional intent behind, and a statement of purpose for, the establishment of the LEAA).

51. See 18 U.S.C. $\$ 4351$ (1994).

52. See 42 U.S.C. $\S \S 1997-1997 j$ (1980), amended by Prison Litigation Reform Act of 1996, Pub. L. No. 104-134, 110 Stat. 1321 (1996). (1994).

53. See Pub. L. No. 103-322, §§ 30201-30208, 31001-31002, 108 Stat. 1796

54. 42 U.S.C. $§ 1997 a(a)$ (1996). 
to substandard conditions, it legitimated the role of the courts in pressing for improvements in these institutions. Although CRIPA has never been used vigorously, it remains something of a sleeping giant: Under an aggressive administration it could be used to effect far-reaching changes in the nation's custodial institutions. More generally, its very existence is testimony to the fact that in the conditions cases the federal courts were not out on a limb by themselves. Although the courts may have been there first, the other branches followed suit. All three branches of the national government are now thoroughly imbricated in the formulation of policy for and oversight of state and local custodial institutions. With relatively little fanfare or resistance, federal involvement with corrections has come to resemble federal involvement with other policy areas: education, transportation, welfare, and police, to name a few.

Admittedly, some of this national commitment has been rolled back in recent years, although it has not been brought to a halt. Growing pressure from prison officials about "frivolous" suits, continuing complaints from federal judges about overcrowded dockets, and mounting get-tough-on-crime pressures coalesced in the early $1990 \mathrm{~s}$, and all branches of the national government retrenched. Appellate courts cut back on standing and took other steps to trim the power of trial courts. Congress adopted the Prison Litigation Reform Act (PLRA) ${ }^{55}$ in 1996 that erected still more obstacles in the paths of would-be prisoner petitioners, and limited the scope and duration of the role of special masters in ways that precipitated a marked decline in complaints filed by individual inmates. ${ }^{56}$ And public officials everywhere embraced longer sentences and supported construction of new prisons. Despite all of this, neither the PLRA nor other actions have sought to undo the central substantive gains of the earlier litigation. Although massive class actions are now largely a thing of the past and individual prisoners have much more difficulty in successfully petitioning the federal courts, ${ }^{57}$ these cut backs have not stymied class actions seeking struc-

55. Pub. L. No. 104-134, 110 Stat. 1321 (1996) (codified as amended at 18 U.S.C. $\S 3626 ; 28$ U.S.C. $\S \S 1346,1915 ; 42$ § U.S.C. 1997 and other scattered sections).

56. See Margo Schlanger, Inmate Litigation, 116 Harv. L. REv. 1157 (2003).

57. See id. 
tural reforms altogether. Structural reform on the order of Ruiz ${ }^{58}$ or Holt $v$. Saver ${ }^{59}$ may no longer be attainable, but corrections departments are still being sued to expand and improve services. Corrections officials we have spoken to in California report that, despite CRIPA and an increasingly conservative federal appellate judiciary, experienced litigators can and do still successfully litigate conditions issues pertaining to medical services, mental health services, and conditions in women's prisons.

\section{Reform through the Expansion and Constitutionalization of Rights}

The prison conditions cases can only be understood as a part of the much broader rights revolution. Indeed, the very term "prisoners' rights movement" reflects roots in the civil rights struggle. Prison reform litigation is a lineal descendant of Brown v. Board of Education ${ }^{60}$ and the rights movement that it spawned. Many of the leading litigators-Alvin Bronstein ${ }^{61}$ of the ACLU's National Prison Project, as well as William Turner, ${ }^{62}$ attorney in the Texas case, Ruiz $v$. Estelle, and Philip Kaplan $^{63}$ in the Arkansas case, Holt $v$. Sarver-had extensive experience in civil rights litigation in the South prior to shifting their interests to prisons. Indeed, they all thought of their prison litigation as a natural extension of their earlier work. Although the courts played a significant role in this process, they were not alone either. The struggle for civil rights took place in many forums and locations. Although there is debate about how important the courts were in the struggle, everyone would agree that the struggle eventually resulted in an expanded set of nationally recognized rights that came to be acknowledged and protected by all branches of the national government. ${ }^{64}$ Here too, the struggle for prison reform paral-

58. Ruiz v. Estelle, 161 F.3d 814 (1998).

59. 309 F. Supp. 362 (E.D. Ark. 1970), affd by, 442 F.2d 304 (8th Cir. 1971).

60. 347 U.S. 483 (1954).

61. Feeley \& Rubin, supra note 1 , at 106.

62. Id. at 81 .

63. Id. at 61-62.

64. See Rosenberg, supra note 3; see also Michael W. McCann, Rights at Work: Pay Equity Reform \& the Politics of Legal Mobilization (1994). 
lels, and must be understood as part of, this larger development.

However, prison conditions litigation can be understood as part of another, more specialized development-the constitutionalization of the criminal process. Beginning in the 1930s but accelerating markedly in a series of landmark rulings in the 1960 s, the Supreme Court in effect constitutionalized state criminal procedure. The earliest cases focused on the judicial process, insisting upon minimum standards for a fair trial, ${ }^{65}$ and then expanded to include the right to counsel ${ }^{66}$ and the superintendence of capital punishment. ${ }^{67}$ Another set of cases established constitutional standards for police. ${ }^{68}$ Thus having established constitutional standards for courts and cops, it was a small step to extend oversight to the third component of the criminal process, corrections. In this sense, the prison conditions cases of the 1970 s and 1980 s are the final step in a constitutionalization of the criminal process that had began in the 1930s.

Perhaps the closest parallel to national efforts to improve prison conditions are the parallel efforts to reform police departments. Through a combination of inspired national leadership, the development of countrywide standards, and the press of professionalism and litigation, American police departments have undergone a major transformation in the past forty years. ${ }^{69}$ Vast areas of practice once exercised at the non-reviewable discretion of individual officers have been domesticated by constitutional law imposed by the courts and internal regulations promulgated by police departments. According to the leading student of this development, Samuel Walker, courts have played-and continue to play-an important part in this development. However, he emphasizes, they are just one of several institutions that have pressed successfully for increased accountability. ${ }^{70}$

65. See, e.g., Powell v. Alabama, 287 U.S. 45 (1932).

66. Gideon v. Wainwright, 372 U.S. 335 (1963).

67. Gregg v. Georgia, 428 U.S. 153 (1976). (1966).

68. See Mapp v. Ohio, 367 U.S. 643 (1961); Miranda v. Arizona, 389 U.S. 436

69. See generally Debra Livingston, Police Reform and the Department of Justice: An Essay on Accountability, 2 BuFf. L. REv. 815 (1999).

70. See Walker, supra note 10; see also TAMING the System, supra note 10. 


\section{Towards Bureaucratization}

Although they were motivated by different concerns and supported by different groups, the efforts described above all contributed to further rationalization of correctional systems. They were part of a process designed to drag pre- and underbureaucratic (and at times, feudal) criminal justice institutions into the modern administrative world. They may have differed in emphasis and conflicted in important detail, but they shared the same aim of modernizing the criminal process. Even the standards setting projects launched by the $\mathrm{ABA}$ and supported by the LEAA and other national efforts in the 1960s (established to stymie the efforts of the Warren Court) had as their central goal the establishment of national standards. ${ }^{71}$ In the case of prisons, this typically meant more resources and further bureaucratization in order to bring corrections into the mainstream of public administration.

The effects of this project of modernization are dramatic and readily apparent. Nearly twenty-five years ago, James Jacobs could describe the prisons he had observed just a few years earlier:

There were no written rules and regulations, and daily operating procedures were passed down from one generation to the next. Wardens spoke of prison administration as an "art"; they operated by intuition. The ability of the administration to act as it pleased reinforced its almost total dominance of the mates. ${ }^{72}$

Today all this has changed. Even a cursory glance reveals how dramatic the changes have been. For instance, with an FY2003 budget of $\$ 5.7$ billion dollars, a staff of approximately 50,000 responsible for thirty-two prisons, ${ }^{73}$ and an organizational chart so complicated it cannot be presented on a single letter-sized page, ${ }^{74}$ the California Department of Corrections (CDC) is a bureaucratic behemoth. Though it is the nation's largest prison system, the $\mathrm{CDC}$ is by no means unique in its relative size or the complexity of its organizational structure. California's prison system, along

71. See supra notes $38-39$ and accompanying text.

72. Jacobs, supra note 7 , at 458 .

73. See Calif. Dep't of Corr., About the Department, at http://www.corr.ca.gov/ CommunicationsOffice/facts_figures.asp (last visited Aug. 22, 2004).

74. Calif. Dep't of Corr., Department Organizational Chart, available at http:/ /www.corr.ca.gov/Personnel/OrgChart.pdf (last visited Aug. 22, 2004). 
with every other state's, has undergone tremendous changes brought about in part by litigation.

Over the past thirty years, prison systems around the country have not just expanded in numbers of inmates and guards, they have undergone a distinct process of bureaucratization that has shaped institutional mission and structure in a host of specific, identifiable ways. An analysis of the bureaucratic transformation of American prisons is well beyond the scope of this article, ${ }^{75}$ and so we must content ourselves with outlining some of the most salient features of this transformation.

In doing so, we turn to Max Weber, who first and most clearly identified the importance of bureaucracy for modern societies, and to Victor Thompson, who systematically applied Weber's insights to the analysis of American public administration. Weber was the first to methodically identify the key criteria of the bureaucratic form. ${ }^{76}$ Compared to other forms of organization, he argued, modern bureaucracy is defined by a rationalized set of rules and regulations that bind the organization together. ${ }^{77}$ Every office is arranged in a clear hierarchy of superordination and subordination, with employees subject to a rigid and systematic set of policies designed to maintain control and discipline when necessary. ${ }^{78}$ Offices within the bureaucracy are characterized by their fixed and definite division of organizational responsibility, and are staffed by highly trained officials who are appointed by merit, have set salaries and pensions, secure careers, and duties that are clearly separated from their private life. ${ }^{79}$

In the United States, Thompson extended Weber's idea to contemporary American public administration, ${ }^{80}$ and in so do-

75. For an important study of contemporary prison administration, see JoHN I. Dilulio, Governing Prisons: A Comparative Study of Correctional ManAGEMENT (1987). This is an important book, but one that is strangely critical of prison conditions litigation. For a more nuanced view see DiLulio's discussion of prison litigation in his edited volume, JoHn I. DiLulio, Courts, Corrections, AND the Constitution: The Impact of Judicial Intervention on Prisons and Jails (1990).

76. Max Weber, Wirtschaft und Gesellschaft 650-78 (Guenther Roth \& Claus Wittich eds., Ephraim Fischoff et al., trans., 1968).

77. Id. at 973 .

78. Id. at 957.

79. $I d$.

80. See generally, Victor A. Thompson, Modern Organization 10-24 (1961). 
ing emphasized additional characteristics of the modern state bureaucracy: routinization of organizational activity, factoring the general goal into subgoals, formalistic impersonality, categorization of data, classification of persons, slowness to act or to change, and preoccupation with the monistic ideal-the system of superior and subordinate relationships in which the superior is the only source of legitimate influence upon the subordinate. ${ }^{81}$

Taken together, the works of Weber and Thompson provide a framework for evaluating the process of bureaucratization within prisons. Below we provide several examples that demonstrate just how deeply entrenched these features of modern bureaucracy have become in contemporary prisons. Using Weber's and Thompson's criteria to identify core features of bureaucracy, today's correctional systems can be characterized as being: 1) defined by an organizational structure with clear divisions of power and responsibility, 2) bound by a rationalized set of rules and regulations, 3) run by a highly specialized workforce, 4) reliant upon the classification of individuals, and 5) accustomed to the routinization of organizational activity. Though much of the evidence that we provide below has been culled from an ongoing project investigating this process within the California prison system, the examples provided here also reveal a national phenomenon. The process has been so sweeping that an investigation into almost any area of prison operations will turn up evidence of some type of increased rationalization. The examples stand in sharp contrast to the portrait of prisons of the 1950s presented by Jacobs in the quote above. ${ }^{82}$

1. The bureaucratic prison is defined by an organizational structure with clear divisions of power and responsibility. Perhaps the most recognizable aspect of modern bureaucracy is a hierarchical structure with clear duties assigned to each division. Today, every state has a department of corrections that operates under a clearly defined organizational structure. Most of these organizational structures can even be found on the Internet, graphically displayed with hierarchically ordered boxes

81. Id. at 14-20.

82. See supra note 72 and accompanying text. 
describing each division within the department. Though many of the units within these organizations have been a part of the institution from day one, some were created specifically in response to prison litigation.

In 1974, the Supreme Court extended a number of procedural protections to prison inmates. ${ }^{83}$ Shortly thereafter, the California Department of Corrections adopted a set of internal grievance procedures to deal with inmate complaints. ${ }^{84}$ Some time later, the CDC administrators established the Inmate Appeals Unit to handle this new process. ${ }^{85}$ Over the years, the Unit's functions have expanded to include proactive oversight of inmate appeals, and it now operates directly under a Policy and Evaluations Division. The Inmate Appeals Unit receives quarterly reports from each individual prison and assembles an annual report documenting trends in inmate grievances. These reports are used in a proactive way, to identify and then solve the most frequent types of problems that generate inmate complaints. Similarly, the CDC's Facilities Standards and Operations Division was created in the $1990 \mathrm{~s}$ in response to litigation. ${ }^{86}$ Working directly with plaintiff's attorneys and prison wardens, this unit is charged with developing corrective action plans in ways that do not require further litigation.

These illustrations reflect a common practice. Thirty years ago, the editors of the U.C.L.A. Law Review surveyed California prison officials and found that virtually every administrator contacted indicated that they had engaged in some type of institutional changes in anticipation of litigation. ${ }^{87}$ That practice continues today. In a 2001 national survey of prison and jail

83. See Wolff v. McDonnell, 418 U.S. 539 (1974).

84. See Cal. Code Regs. tit. 15, § 1073 (2002) (establishing an "inmate grievance procedure").

85. See Cal. Code Regs. tit. 15, $\S \S 3084$ to 7 (2002) (establishing the right to appeal "any departmental decision ... which [the inmate] can demonstrate as having an adverse effect upon their welfare").

86. See Armstrong v. Wilson, 124 F.3d 1019 (9th Cir. 1997); Clark v. California, 123 F.3d 127 (9th Cir. 1997); see also Calif. Bd. of Corr., Board of Corrections-Major Duties and Responsibilities, Facilities Standards and Operations Division, at http://www.bdcorr.ca.gov/about_boc/htm_docs/aboutboc.htm (last visited Aug. 22, 2004).

87. Jacobs, supra note 7 , at 454-55. 
administrators, Margo Schlanger ${ }^{88}$ reported similar findings: about $70 \%$ of institutions reported some type of operational change in response to litigation. Actions of the respondents ranged from modifying disciplinary policies to adding new and specialized staff positions to establishing entire new divisions. ${ }^{89}$

Although virtually all the successful litigation against prisons was directed against state institutions, the increased bureaucratization it stimulated took hold in the federal prison system as well. Norman Carlson, who headed the Bureau of Prisons from 1970 until 1987 managed to avoid many of the court-ordered reforms by staying, in his words, "one step ahead of the courts." 90 Carlson paid close attention to national trends in prison litigation, reorganizing the BOP in line with contemporary professional standards in order to avoid such litigation himself. As illustration, he restructured the federal BOP into five regional units, each with its own headquarters and regional director. In turn, individual prisons then amended their policies so that each wing or "unit" of a prison maintained a team of correctional officers and counselors who were responsible for everything from sanitation to security. Carlson made certain that each policy, mundane and major alike, was institutionalized in writing and backed up with a defensible rationale. One result of such actions, Carlson felt, was that federal prisons were never subject to the types of sweeping conditions litigation common to state prisons. Every time one of the policies or practices in one his prisons was challenged, BOP officials could point to a rule and a rationale for it. ${ }^{91}$ What the BOP did as a matter of course and in part as a successful strategy to avoid litigation, state corrections officials did after the fact, in response to litigation. But the results were much the same in either case.

2. The bureaucratic prison is bound by a rationalized set of rules and regulations. Jacobs identified the process by which a rationalized set of rules and regulations took hold in prisons in

88. Margo Schlanger, Inmate Litigation: Results of a National Survey, LJN EXCHANGE (Nat'l Inst. of Corr., Longmont, Colo.), 2003, at 1, available at http:// www.nicic.org/pubs/2003/period232.pdf.

89. Id. at 8 .

90. John J. DiLulio, Jr., Prisons that Work: Management is Key, FED. PRISONS J., Summer 1990, at 11, available at http://www.bop.gov/ipapg/sum90fp1.pdf.

91. See id. at 10. 
the 1960 s and 1970s.92 Prisoners' rights litigation was successful when prisons and correctional agencies were unable to point to written policies that prescribed regulations and reasons for them. In response, some state legislatures simply began to codify the requirements set forth in major prisoners' rights cases. Other states passed on rule-making authority to their correctional agencies and specified procedures for such authority. In California, prior to 1975 the director of the CDC could simply announce new policies whenever he saw fit. Now the process is quite complex. When it makes revisions to the California Code of Regulations (CCR), the Department of Corrections must adhere to the procedure set forth in the Administrative Procedures Act that requires all proposed new rules to be subject to a public hearing and comment process. ${ }^{93}$ The CDC must then respond to each comment, and, according to a recent law, provide an analysis of the fiscal impact of the new rule. ${ }^{94}$ The final version of the rule must then undergo further scrutiny by the Office of Administrative Law and be reviewed by the Secretary of State before final approval. ${ }^{95}$ Revisions to the CCR that affect the Departmental Operations Manual must also be announced in the Notice of Change to Departmental Operations Manual and distributed to individual prisons. ${ }^{96}$ This new procedure is complicated, and staff routinely complains about "the Bureaucracy," "red tape," and "tied hands," and officials have devised a host of ways to circumvent the process. Rather than announcing "general" rules that initiate this complicated process, superintendents of individual prisons routinely announce "unique" findings that trigger practices that are limited to only their institutions, and in so doing avoid the lengthy announcement and comment process. ${ }^{97}$

Still, this process has entangled the CDC in the statewide administrative process. The CDC is now subject to the state's

92. Jacobs, supra note 7 , at $458-59$.

93. See Cal. Gov't Code $\S 11346.4$ (West 2001); see also Cal. Code Regs. tit. 1 , 5 (2004); CaL. Code Regs. tit $1, \S 44$ (2004).

94. See Cal. Gov't Code $\S 11346.5(a)(6)$ (West 2001).

95. See CaL. Gov't Cop̣e $\S 11349.1$ (West 2001).

96. See generally CAL. Gov't CODE $\S 11346.4$ (West 2001); Calif. Dep't of Corr., Change of Department Opernations Manual Notice, at http://www.corr.ca.gov/RegulationsPolicies/Pages/NCDOM2002.asp (last visited Aug. 22, 2004).

97. See Cal. Penal Code $\S 5058(c)(1)$ (West 2003). 
general requirements for rule making. Together title 15 of the CCR, the section of the Code that addresses the Department of Corrections, and the Department's own Operations Manual run to more than 1500 printed pages and cover virtually every aspect of correctional operations. Indeed, it is difficult to imagine an issue that is not addressed in this document. For instance, food service standards are presented in minute detail in the Code of Regulations. To wit: article 4, section 3051 requires that "A menu shall not include only one vegetable if pork or a pork derivative was used in the preparation of the dish. A porkfree version of the vegetable shall be provided."98 Although the Department of Corrections had published "plans" for menus long before the commencement of prisoners' rights litigation, they were neither mandatory nor so sensitive to dietary concerns of religious minorities. Litigation was an important impetus for increased specification and content, as well as the fact that suggested menus were transformed into bureaucratic requirements.

3. The bureaucratic prison relies upon a highly specialized workforce with extensive training. One of the most notable changes remarked upon by senior prison administrators is the shift away from the "old guard" culture of the pre-bureaucratic institution. ${ }^{99}$ Older staff recall the days when criminal offenders, once sentenced, lost virtually all rights. Now prison administrators universally acknowledge that inmates possess a host of rights. This shift is partially a result of changes in recruitment and training. As one senior CDC official observed of the younger, more bureaucratically-minded staff, "they are more educated, better trained, and are now in supervisory positions." 100 Slowly, but surely, prisons have gotten rid of the old guard. But the shift is also due to changes in the new bureaucratic culture itself.

This change in the increased specialization of the workforce can be seen in the personnel requirements outlined by the CDC's Office of Personnel Management. Using a process called "Job Analysis" to identify the entire set of tasks, knowledge,

98. CAL. Code Regs. tit. 15, §3051(c) (2003).

99. Interview with Anonymous California Department of Corrections Administrator (Oct. 23, 2003).

100. Id. 
skills, and abilities required to perform a particular job, the department defines each job classification within the CDC in exhaustive detail. ${ }^{101}$ Originally developed to comply with the 1978 Federal Uniform Guidelines on Employee Selection Procedures Act, ${ }^{102}$ "Job Analysis" is a widely recognized tool used by the department to make employment and management decisions, save money, and increase productivity. The CDC now routinely relies upon the updated "Western Regional Intergovernmental Personnel Assessment Council"103 Job Analysis method for classifying over 500 different positions within the department.

One example will illustrate the high degree of specialization within the CDC. The position of "Facility Captain" is associated with twenty-six different "tasks." 104 The first requires a captain to be able to:

Interpret and carr[y] out the policies of the Department of Corrections (DOC) using the California Penal Code, California Code of Regulations (CCR) Title 15, Departmental Operations Manual (DOM), Institutional Operational Procedures (IOP), Administrative Bulletins (AB), etc., to ensure public safety, safety of staff and inmates, etc., under the direction of the Correctional Administrator and indirectly by the Chief Deputy Warden or Warden. ${ }^{105}$

In addition, the Facility Captain must also possess six "knowledges," five "skills," three "abilities," and one "special personal characteristic."106 Whatever else he is, a Facility Captain is not just one of the good ol' boys. California corrections is now thoroughly ensconced in the state's increasingly bureaucratic civil service system. Although litigation may have hastened this in-

101. See Calif. Dep't of Corr., Personnel Examinations, Job Analysis, at http:// www.corr.ca.gov/Personnel/exams/jobanalyses/jobanalysis.asp (last visited Aug.
22, 2004).

102. 29 C.F.R. $\S \S 1607.1$ to .18 (1982).

103. See Western Region Intergovernmental Personnel Assessment Council, at http://www.wripac.com/ (last visited Aug. 22, 2004).

104. Calif. Dep't of Corr., Facility Captain, Edited Task Listing, available at http://waww.corr.ca.gov/Personnel/exams/jobanalyses/pdfs/FacilityCaptain/task. pdf.

105. Id. at Task 1.

106. See Calif. Dep't of Corr., Facility Captain, KSA Listing, available at http://www.corr.ca.gov/Personnel/exams/jobanalyses/pdfs/FacilityCaptain/KSA. pdf. 
corporation, once there the process has taken on a dynamic of its own.

Corrections departments elsewhere have also been subject to increased specialization as a consequence of litigation. In fact, most prison systems have established specialized positions just to handle litigation. Each prison in the Colorado Department of Corrections has a "facility litigation coordinator" who acts as a liaison between the prison and a central office of Legal Services. ${ }^{107}$ Departmental regulations outline the responsibilities for the holder of this position and list procedures that they must follow. For states that have internal grievance procedures, each prison usually has an appeals coordinator who reports directly to the warden. The appeal coordinator is responsible for logging inmate appeals and assigning them to the proper staff member. Similarly, medical facilities have medical appeals analysts who perform similar functions. Typically these and other executive staff meet with the prison warden weekly to discuss trends in inmate litigation and grievance issues.

Another characteristic of the specialization within modern prison bureaucracies is the commitment to highly trained staff. The Virginia Department of Corrections has its own training division, the Academy of Staff Development, which has been involved in employee training and development since 1976. ${ }^{108}$ That department provides training for positions at every level, from basic correctional officers to management to food service to mental health. In addition to assuring competence among staff, training acts as a managerial tool to secure compliance with departmental rules and as a means for institutionalizing court orders.

4. The bureaucratic prison emphasizes inmate classification. Twenty years ago a non-violent drug offender sentenced to three years in an Arizona prison could be placed in a cell with an inmate who had a history of violence and mental instability and was serving a life sentence. Now such pairing is unlikely. A consent decree in the 1983 case, Harris $v$. Caldwell, required prison officials to establish and then follow a set of standards

107. FEELEY \& RUBIN, supra note 1 , at 108.

108. See Va. Dep't of Corr., Academy for Staff Development, at http://www. vadoc.state.va.us/about/training/default.htm (last visited Aug. 22, 2004). 
for classifying and placing all incoming inmates. ${ }^{109}$ Similar reforms have taken place in every prison throughout the country, some as a result of litigation and others not. Just as correctional staff is classified according to knowledge, skills, abilities, and tasks, so too inmates are now assigned to specific institutions, units, and cells according to their propensity for violence, length of sentence, criminal history, and the like. ${ }^{110}$

Although inmate classification is hardly new-it, too, predates litigation and is still one more example of the courts requiring prison officials to follow their own suggestions-in recent years it has become something of a high art, considerably more complex than it once was. Indeed, since a unanimous 1998 Supreme Court ruling, the Americans with Disabilities Act applies to state prisoners. ${ }^{111}$ Everywhere, corrections departments have had to develop facilities to meet the specialized needs of disabled inmates as well as the capacity to generate inmates' mental and physical disability profiles, no small task given their problem-prone population. The expectation is that, if done properly, diagnosis and classification will at one and the same time promote rehabilitation, safety, and security. As one senior prison administrator we interviewed put it, "if we've done our job correctly, the inmate will get the best treatment because of good placement." Showing pride in the system's efforts to meet the needs of disabled inmates, he went on to say, "inmates with disabilities get better treatment than many people who live in cities." Furthermore, he concluded, "accurate assessment and classification will reduce inmate violence and protect both the prison and the prisoner."112

5. The bureaucratic prison provides a formal set of rules and procedures that routinize organizational activity. Immediately following the Supreme Court's decision in Wolff v. McDonnell, ${ }^{113}$ the California Department of Corrections adopted an

109. See Ariz. Dep't of Corr., 1998 Annual Report: The Past Thirty Years, at http://www.adc.state.az.us/AR98/AR98-30.htm (last visited Aug. 22, 2004).

110. See James Austin \& Kenneth McGinnis, Classification of High-Risk and Special Management Prisoners: A National Assessment of Current Practices (2004), available at http://www.nicic.org/pubs/2004/019468.pdf.

111. Yesky v. Penn. Dep't of Corr., 118 F.3d 168 (3d Cir. 1997).

112. Interview with Anonymous California Department of Corrections Administrator (Oct. 23, 2003).

113. 418 U.S. 539 (1974). 
internal appeals process to handle inmate grievances. This process is now described at length in the California Code of Regulations, ${ }^{114}$ and is implemented according to rules of the Department of Corrections Operations Manual. Under this procedure, inmates "may appeal any departmental decision, action, condition, or policy which they can demonstrate as having an adverse effect upon their welfare" by filing a grievance petition. ${ }^{115}$ The regulations governing the process presents a system of four levels of review: one informal level and three formal levels. ${ }^{116}$ Inmates must exhaust the appeals process before filing suit in federal court.

When the grievance procedures were first implemented in the CDC, officials looked upon the process as one more bureaucratic burden. However, they came to appreciate that this grievance mechanism could be a tool for dealing with the daily frustrations of inmate life. California officials came to believe that states without such measures are more likely to experience prison disturbances, and wardens began to use the appeals system as a means for identifying recurring inmate problems as a first step towards corrective action and new forms of staff training.

The discussion above is only illustrative. It is meant to suggest the variety of ways that the U.S. prison system has been bureaucratized in response to the prisoners' rights movement. Drawing on other aspects of Weber and Thompson's analysis of bureaucracy would yield still further insights into and examples of this process. Prison conditions litigation and the various forces it unleashed and reinforced have contributed significantly to this process over the past several decades. Although the process has been incremental, is often contentious, and is still ongoing, its mark can be seen in just about every facet of modern prison administration.

114. See Cal. Code Regs. tit. 15, $\S 3084$ to .7 (2002).

115. CaL. Code REgs. tit. 15, §§ 3084.1(a) (2002).

116. Cal. Code Regs. tit. 15, $\S \S 3084.5$ (2002). 
IV. Conclusion: Assessing the Twin-Edged Effects of the Prison Conditions Cases-Prisoners' Rights and Bureaucratic Control

The discussion above can be summarized as follows: prison conditions litigation has been successful because lawyers bringing the cases were able to convince judges to abandon their traditional role as appliers of rules and embrace a policy making approach. In taking this new course of action, the courts began to look like executive agencies. They adopted goals and developed strategies to achieve them, including the creation of staffs charged with overseeing their implementation. They succeeded in this effort because their agenda was already well-defined. The appropriated a model of the modern bureaucratic prisons that had been developed and aggressively advanced by the corrections profession itself. However, this judicial embrace of policy making is only a partial account of the success of their effort. Litigation must be understood in the context of the more general movement to modernize and impose national standards on prisons. The courts were part of this broader project.

In this section, we explore some of the implications of this project. In particular, we explore the double-edged sword of bureaucracy. Even as it protects and limits against arbitrary power, bureaucracy can also enhance and mask authority. This, we think, goes a long way towards explaining why prison conditions litigation quickly came to be accepted by corrections officials themselves. Put succinctly, the reforms ordered by the courts not only extended protections and services for inmates, it increased the efficiency and effectiveness of prison administrators as well. Enhanced bureaucracy meant a stronger organization.

A conventional view of bureaucracy sees it as the enemy of democracy, freedom and rationality, and the triumph of organization over the individual. Hierarchy wars against representation, domination challenges spontaneity, and capriciousness extinguishes reason. Max Weber hints at this in his metaphor of the iron cage. ${ }^{117}$ And Franz Kafka's writings often depict Every-

117. Max Weber, The Protestant Ethic and the Spirit of Capitalism, 181 (Talcott Parsons trans., 1950). 
man caught in a bureaucratic nightmare. ${ }^{118}$ If these images represent one aspect of bureaucracy, they also ignore another. For bureaucracy is double-edged. If it restricts freedom, it also constrains power. If it imposes limits, it also empowers. If it squashes spontaneity, it also respects expertise. If it restricts personal prerogative, it also purges particularism. If it imposes red tape that hampers, it also promulgates rules that clarify. If it imposes hierarchy that stifles, it harnesses the energies of large numbers to common purpose. Like the law generally, modern public bureaucracy empowers even as it limits.

In large-scale organizational settings, bureaucracy does not just foster the role of law; it is the role of law. Modern public bureaucracy is rational-legal organization, and as such it is a web of rules and regulations whose legitimacy stems from the authority of law itself. In this sense, as Weber instructs us, modern public bureaucracy is a form of rational-legal authority that replaces tradition and the force of personality as the basis of authority. In essence, it has all the weaknesses and strengths of law. It can cloak conflict in the guise of consensual roles and mask power in the guise of due process. It can suppress local culture in the pursuit of abstract universals or general principles. It can be the iron fist cloaked in the velvet glove. But law also imposes a regime of rights and duties that clarify responsibilities and standardize relationships. Through a web of rights it can locate and protect the individual, and through a web of duties it can define and constrain power.

It was this connection between bureaucracy and law that transformed litigation to assure prisoners' rights into an effort to strengthen prison bureaucracy. Despite the concern with individual rights, the language of prison conditions litigationthat of both plaintiffs' attorneys and judges-is the language of bureaucratic development. Issues were immediately characterized in terms of organizational competence, not individual rights. ${ }^{119}$ Although odd at first blush, there is no contradiction in this transformation. Prisoners' rights are about guarantee-

118. See, e.g., Franz Kafka, The Penal Colony: Stories and Short Pieces (Willa Muir \& Edwin Muir trans., 1976); Franz KafKa, The Trial (Willa Muir \& Edwin Muir trans., 1937).

119. Contrast these with more rights-oriented police procedure rulings. See, e.g., Miranda v. Arizona, 384 U.S. 436 (1966); Mapp v. Ohio, 367 U.S. 643 (1961). 
ing rights of individuals, and so too bureaucratic development is about extending the role of law. In the case of custodial institutions, the best way to protect individual rights is through structural reform. In the context of prison conditions, this meant transforming traditional organizations or underdeveloped bureaucracies into modem rational-legal bureaucracies, and teaching those who staffed these new bureaucracies to value these roles. Thus from the outset the concern with the individual rights of prisoners was understood by the courts, as well as plaintiffs' attorneys and the defendants themselves, as a concern with structural reform of the organization.

There is an irony in all this: seeking to protect individual rights by strengthening prison administration! But protecting prisoners' rights and strengthening prison administration is not a zero-sum game. One need not be purchased at the expense of the other. Indeed, in an institutional setting, it is inconceivable that individual rights could be enhanced without strengthening organizational capacity. Structural reform of institutions requires clarification of mission, which in the case of prisoners' rights means enhancing concern for the dignity of inmates. But it also means imposing on the organization a regime of rules to replace particularistic practices. Thus a stronger prison organization, under a rational-legal bureaucratic regime, can foster increased rights for prisoners.

But strengthening prisoners' rights through bureaucratic enhancement also strengthens the prison administration's capacity to control. Better conditions for inmates, improved due process, enhanced oversight and answerability, more resources and all that these imply in prison settings, not only protect individual inmates, but also enhance the institution's capacity to control. Even as these rights erect zones of protection around inmates, they also strengthen organizational capacity to clarify goals, improve accountability, reduce particularism, gather and interpret information, recruit more skilled employees and add more resources. In short, strong bureaucracy is an efficient means of clarifying goals and orienting people towards these goals. This is, as Weber noted, the awesome power of bureaucracy. ${ }^{120}$

120. See Weber, supra note 76 , at $973-80$. 
The double-edged nature of conditions litigation also helps explain why so many prison administrators almost immediately came to welcome judicial intervention. Unlike Southern politicians who opposed school desegregation orders because they sensed desegregation would alter power relationships, and unlike police and other public officials who failed to see the link between exclusionary rules and improving police departments, most prison officials realized immediately that prison conditions-as distinct from prisoners' rights-litigation would redound to their benefit. Indeed, rumors abound that many of them secretly kindled such suits. This may also help explain why prison conditions litigation was at its zenith not during the height of the "rights revolution," but at a time when the movement to promote "system" efficiency and expand prison capacity was near its height. Far from being antithetical to each other, the ACLU's National Prison Project, which sought to enhance prisoners' rights, the Department of Justice's Law Enforcement Assistance Administration, which provided funding to foster professional standards and enhance system efficiency, and the American Correctional Association's campaign to professionalize correctional administration, are more closely related than they might first appear to be. The apparent paradox is obvious: increase rights of vulnerable prisoners by strengthening the capacities of correctional institutions themselves. But in fact, in a bureaucratic setting, the former implies the latter. Indeed they are two sides of the same coin. At one and the same time the rule of law and bureaucratic development both empower and limit.

Consider one rather mundane example. In 1982 a federal court ruled that conditions in the Alameda County (Oakland, California) jail were unconstitutional. Included in the court's ruling was a finding that food service was unacceptable-food was often substandard, was prepared by inadequately trained personnel in a kitchen with leaky sewage pipes that ran across the ceiling, was cold when served, and at times was arbitrarily withheld from inmates. ${ }^{121}$ Initially angry at being sued, Sheriff Charles Plummer soon saw that the suit could help him obtain a new, long-planned jail and that it could in fact help him ob-

121. Smith v. Dyer, Nos. 74184, 63779, 76086, 750121 (Cal. Super. Ct. Aug. $15,1983)$. 
tain a larger, better-equipped facility than he otherwise might. So he helped write specifications into the consent decree that went well beyond anything the court would have ordered. ${ }^{122}$ When the crafty sheriff showed one of the authors around the recently opened jail, he was proud of the food service facilities and his strategy. He showed us an up-to-date kitchen supervised by a newly hired dietician. But the coup de grace was the delivery system. Food was placed in Styrofoam trays, packed into warming containers and delivered to inmates on a computer controlled, driverless trolley that automatically uncoupled a cart in front of each inmate housing unit. The inmates clearly benefited: quality control was dramatically improved. And the possibility of arbitrariness was all but eliminated as partitions were standardized and the distribution was mechanized. So, too, the control system benefited, and per-unit staffing costs were decreased. Furthermore, safety and security were enhanced-although it can be argued that it is beneficial to allow large numbers of inmates to walk through corridors and eat in a central dining hall, it is difficult to argue that they are deprived of a constitutional freedom by bringing warm, nutritious food to groups of 50 to 200 inmates in their own common areas. And while some might find the high-tech design of the new jail chilling, no one would make an argument that the higher staff-to-inmate ratio it allows is unconstitutional. What occurred here can be multiplied many times over, as improvements in conditions for inmates simultaneously increased the system's ability to control inmates and operate more efficiently.

The new structures and the increasingly rational-legal bureaucratic system in which they are ensconced rests upon a much firmer and more powerful form of authority than the old prison systems provided. Inmates are now safer, ${ }^{123}$ and receive more and better services, but prison officials command more effective power. Of course improvements brought about by this development in bureaucratic rationalization must be off-set against the burgeoning prison population, the rise of prison gangs, and a host of pathologies that are endemic to even the best-run prisons. Still, no one-prison inmate or correctional

122. Feeley \& Rubin, supra note 1 , at 363.

123. See, e.g., Ben Crouch and James Marquart, An Appeal to Justice: Lit. igated Reform of Texas Prisons 216-20 (2000). 
officer alike-would now seriously entertain the idea of turning back the clock to the pre-bureaucratic prison. Indeed, the awesome new problems confronting prisons can be handled as well as they have been only as a consequence of the enhanced capacities brought about by increased bureaucratization.

But increased bureaucratization is a double-edged sword for still another reason. Lauren Edelman and various collaborators have written extensively about the problems of institutionalizing rights in an organizational setting. ${ }^{124}$ Focusing on business' responses to anti-discrimination laws, they have found that although companies may be responsive to legal protections of employees' rights, internal regulations and grievance procedures that have been developed are often empty shells. When the authors scratch beneath the surface and take stock of these new arrangements, they have often found more form than substance. Businesses have been quick to seize on the language of the law and develop structures that appear to be responsive to newly articulated rights and newly required grievance procedures. But they often leave the explanation of employees' rights to "human resources" divisions that translate hard-edged employee rights into vague quests for "diversity," and oversee hearings that reshape petitions for the vindication of rights into group counseling sessions that allow disgruntled employees to express their feelings in order to foster better communication. Such activities may be beneficial in various ways, but they are not responsive to the issues that gave rise to them. ${ }^{125}$ The organization's rational legal response gives the appearance, but not the reality, of responsiveness. Furthermore, Edelman and her colleagues report, when employees turn to litigation, courts tend to defer to their employers whenever it appears that welldeveloped policies and procedures have been put in place. The courts are reluctant to peer beneath the surface and businesses

124. Lauren B. Edelman \& Stephen M. Petterson, Symbols and Substance in Organizational Response to Civil Rights Law, 17 Res. In Soc. STRATIFICATION AND MoBILITY 107-35 (1999); Lauren B. Edelman et al., The Endogeneity of Legal Regulation: Grievance Procedures as Rational Myth, 105 AM. J. Soc. 406 (1999) Thereinafter Endogeneity of Legal Regulation]; Lauren B. Edelman \& Mark C. Suchman, The Legal Environments of Organizations, 23 ANN. Rev. Soc. 479-515 (1997); Lauren B. Edelman et al., The Transformation of Civil Rights in the Workplace, 27 LAW Soc'y REv. 479 (1993).

125. See id. 
quickly learn that they need to provide very little of substance in order to obtain approval from the judiciary. As courts continue to develop deferential doctrines based upon thin evidence, the authors warn, the new rights and the new procedures may generate more problems than they solve. They may give the appearance of solving problems while in fact accomplishing very little.

What holds for employees' rights in business organizations may also hold for prisoners' rights. Corrections officials may learn that they can ward off judicial scrutiny by adopting only the patina of bureaucratic form. Indeed, something like this has occurred with respect to dealing with inmate grievances. Litigation (and at times, standards and national legislation) has led to the widespread adoption of procedures to handle inmate grievances. Yet an analysis of the operations of such procedures reveals something of a Potemkin's village. On the surface they appear to be fair and forthright, but as operated they accomplish little. Although there may be written regulations spelling out inmates' rights, those charged with handling grievances may not be familiar with these rules or have little or no training as to how to administer the process. For instance, one of the authors examined the inmate grievance process in the California prisons, and found that those charged with handling inmate grievances have little knowledge of applicable rules, have inadequate training for the specific task and are at times hostile to the process. "Instead of relying upon legal doctrines [to resolve complaints]," he found, "many complaint handlers turn to their own conceptions of what constitutes fair treatment."126

To the extent that what Edelman and her colleagues have found among businesses in their responses to anti-discrimination laws and Swearingen has found in the California prison system with respect to handling inmate grievances is generalizable, increased bureaucratic rationalization may mask problems as well as solve them. This, of course, is a familiar feature of bureaucracy, and one of the reasons that the very term bureaucracy is synonymous with unresponsiveness. Fur-

126. Van Swearingen, Imprisoning Rights: An Investigation of the California Department of Corrections' Internal Grievance Procedures (2003) (unpublished manuscript, on file with the authors). 
thermore, this process exacerbates problems in that it provides form without substance, and gives the appearance of being responsive to problems while burying them. As we saw, the Federal Bureau of Prisons adopted a policy of staying one step ahead of the courts in an effort to ward off litigation. ${ }^{127}$ Some state prisons have followed this lesson.

Edelman's work suggests that organizations adopt rational responses to legal threats based upon their understanding of appropriate responses that are themselves modeled after traditional modes of law. ${ }^{128}$ These efforts-which began as gestures of compliance-are then recognized and legitimated by courts. The prison accreditation process is one such example. After decades of judges having held up professional associations' standards as the model to guide prison administration, prison officials have sought out accreditation specifically in order to avoid lawsuits. Prison administrators were not bent on improving the conditions of confinement for their inmates; rather, they were looking for relief from litigation. Undoubtedly, professional associations' certification has benefited the living conditions of inmates. However, the accreditation process provides some leeway for prison administrators to have their say. Twenty years ago, it was common for wardens to obtain waivers from specific ACA standards yet still obtain certification. Although it has become considerably more difficult to circumvent specific standards, the ACA understands the delicate balance between maintaining stringent standards and developing a strong client base: tougher standards result in fewer prisons seeking accreditation. Together, though not necessarily maliciously, prison officials and the ACA have engaged in a process that is both concerned with improving life behind prison walls and creating the appearance of improving life behind prison walls. Both seek to maximize their managerial goals through ostensible attention to prisoners' well being.

Similarly, several departments of corrections have created risk management units to strategically identify problem areas in attempts to minimize liability exposure. Again, the recommendations made by these units are driven by the goal to mini-

127. See supra notes $90-91$ and accompanying text.

128. Endogeneity of Legal Regulation, supra note 124. 
mize the threat of litigation, not immediately out of genuine concern over prisoners' conditions of confinement. As a result, the reforms adopted are more likely to first and foremost meet organizational needs, and only secondarily meet the needs of inmates.

To the extent that the structures erected in this process are genuine and responsive to the issues they address, this is all to the good. But to the extent that they emulate the sorts of responses that businesses have given to anti-discrimination law, they foretell of deeper conflicts. And even if they are conceived with good will, as David Rothman has reminded us, a great many prison reforms were born of conscience only later to founder on convenience. ${ }^{129}$ Given the pattern of neglect and scandal and half-hearted reform that has characterized the history of prisons since they were first established, ${ }^{130}$ there is no reason to believe that prison conditions litigation or the bureaucratic rationality that it has spawned constitutes the end of history for this seemingly endless cycle.

Max Weber anticipated much of this. He saw the value, indeed the necessity, of rational-legal bureaucracy in modern, complex society. And he saw that the rule of law and rational organization were two sides of the same coin. He also anticipated the tensions and issues identified in the prison conditions cases examined in this article. He appreciated the power, the predictability, the protection, and the harnessing of energy that rational bureaucracy yields. But he also saw the down side: rigidity, impersonalism, domination, and control. Thus he came to regard the development as a mixed blessing, an ongoing insoluble dilemma that would continue to beset modern societies. ${ }^{131}$ The challenge is of course to determine the proper balance between the contending impulses. The modern constitutional prison may also be a mixed blessing. Conditions and practices are much improved, and the constitutionalization of the process assures that these improvements are likely to be permanent. But bureaucratic form can easily be mistaken for

129. See David J. Rothman, Conscience and Convenience: The Asylum and its Alternatives in Progressive America (1980).

130. See Michel A. Foucault, Discipline and Punish: The Birth of the Prison (A. Sheridan trans., 1977); see also RothHMAN, supra note 131.

131. WEBER, supra note 76 , at $975-80$. 
substance. And whatever else the prison is, its central missions remain the pursuit of safety and security by means of a tight system of control. Litigation has made prisons more-not less-effective and more efficient in the pursuit of this mission, and it has provided departments of corrections with a new form of legitimacy. And whatever their initial response to lawsuits, corrections officials almost everywhere have come to realize that, even as it benefits inmates, litigation can also be used to strengthen control systems and increase their legitimacy. Perhaps nowhere else is the metaphor of the "iron cage" as apt as it is with respect to the modern, bureaucratic constitutional prison. 
HeinOnline -- 24 Pace L. Rev. 476 2003-2004 